\title{
Verbal Rating Scale 4-Point
}

National Cancer Institute

\section{Source}

National Cancer Institute. Verbal Rating Scale 4-Point. NCI Thesaurus. Code C158271.

A type of verbal rating scale composed of 4 items. 